\title{
Management Entrenchment, Agency Problem and Audit Fees
}

\author{
Xinhua Wang (corresponding author) \\ International Business Faculty, Beijing Normal University, Zhuhai Campus, China \\ $\&$ \\ School of Accounting and Finance \\ The Hong Kong Polytechnic University, Hung Hom, Kowloon, Hong Kong SAR \\ Tel: (852)-2766-7404Ｅ-mail: lgtbb@inet.polyu.edu.hk
}

Bibo Yang

Graduate School of Business

The Hong Kong Polytechnic University, Hung Hom, Kowloon, Hong Kong SAR

Tel: (852)-2766-5087Ｅ-mail: bibo.yang@inet.polyu.edu.hk

\begin{abstract}
Received: September 5, 2011 Accepted: November 8, 2011 Published: December 1, 2011
doi:10.5296/ajfa.v3i1.932 URL: http://dx.doi.org/10.5296/ajfa.v3i1.932
\end{abstract}

\begin{abstract}
This study examines the association between audit fees and management entrenchment, which is proxied by Bebchuk et al. (2005) entrenchment index. The results show that audit fees are significantly positively correlated with Bebchuk et al. (2005) entrenchment index controlling for other factors. Further results show that the positive relation between audit fees and the entrenchment index exists only in firm with low growth opportunity and high free cash flow (i.e. firms with severe Jensen agency problem). These results indicate that firms' agency problems moderate the association between audit fees and management entrenchment.
\end{abstract}

Keywords: Audit fee, Management entrenchment, Agency problem

JEL Classification: M42, G34 


\section{Introduction}

A number of firms adopt corporate governance provisions to fight against takeover. Although these governance provisions provide possible attempts to fend off being targets of merger and acquisitions, it is of great interest to know whether these governance provisions have any negative effects perceived by either capital markets or external auditors.

Corporate governance provisions have attracted attention from both academics and practitioners. Prior studies on governance provisions focus on the effect of these provisions on market valuation (e.g. Compers et al. (2003), Bebchuk et al. (2005)). This study complements prior studies by investigating whether entrenchment governance provisions result in high level of risk and demand more audit effort by external auditors.

It is reasonable to assume that auditors assess entrenchment provisions in auditing planning. The assumption is valid because auditors are sensitive to firm corporate governance and management control in both preplanning and planning judgment (Cohen and Hanno, 2000). If entrenchment provisions are perceived as higher risk, auditors would charge more audit fees due to more audit effort exercised for high risk clients (other things being equal). If entrenchment provisions are perceived as lower risk, auditors would charge less audit fees since auditors would exercise less audit effort on low risk clients (other things being equal).

Using audit fee data from U.S. firms, we examine whether auditors charge higher or lower audit fees for firms with higher entrenchment index scores controlling for other factors. We further investigate whether the association between audit fees and management entrenchment is contingent on firms' agency problems.

The contribution of this study is two-fold. First, this study contributes to the corporate governance provisions research by providing empirical evidence that entrenchment provisions results in higher audit fees, suggesting entrenchment provisions lead to higher audit risk. This provides one possible explanation why management entrenchment index has a negative effect on firm value. To this end, this study complements Becheck et al. (2005) by providing evidence that entrenchment provisions result in high internal risk, and consequently reduce firm value. Second, this study contributes to the auditing literature by providing empirical evidence that auditors charge higher audit fees for firms with more entrenchment governance provisions. This complements the experimental study of Cohen (2000) by documenting empirical evidence that auditors are sensitive to the corporate governance ontrol of their clients.

The next section develops testable hypotheses. Section three presents methodology used in the empirical tests. Section four describes the sample and section five provides empirical results and reports sensitivity tests. The final section concludes.

\section{Hypotheses Development}

\subsection{Entrenchment Index}

Compers et al. (2003) constructed a board index based on 24 corporate governance provisions and show that the index is negatively associated with firm value. Bebchuk et al. (2005) 
construct an entrenchment index using six of 24 corporate governance provisions, and provide empirical evidence that the negative relation between governance index and firm value documented by Gompers et al. (2003) is driven by the entrenchment provisions (based on six provisions) rather than the other 18 provisions. Among these six provisions, four "constitutional" provisions (staggered board, limits to shareholder bylaw amendments, supermajority requirements for mergers, supermajority requirements for charter amendments) prevent a majority of shareholders from having their way and two "takeover readiness" provisions (poison pills and golden parachutes) defend against a hostile takeover. The entrenchment index ranges from zero to six given equal weight on each of the six provisions. Higher entrenchment index score represents more power for management and places strong restriction on shareholder's ability to exercise their will.

\subsection{Competing Views on Governance Provisions}

There are two opposite views regarding these governance provisions. One view is that these governance provisions weaken discipline mechanism to remove management and thus entrench management. Manne (1965) argues that the entrenchment governance provisions are harmful to shareholders by weakening the disciplinary threat of removal and consequently increase empire building, shirking and stealing. Thus, entrenched management is more likely to be associated with opportunistic and inefficient behavior, which could reduce firm value.

The counterargument is that firms adopt entrenchment governance provisions to attract and retain good managers (i.e. these entrenchment provisions are adopted to insulate managers) because managers who are insulated by these entrenching provisions are more likely to invest optimally in long-term projects (Stein 1988; Bebchuk and Stole 1993) and avoid inefficient actions that otherwise be undertaken to reduce the likelihood of a takeover bid (Arlen and Tally 2003). Thus, corporate governance provisions are used to serve the long-term interests of shareholders by insulating management from focusing on short term. Companies adopt entrenchment provisions to attract good managers to behavior in the way which benefits the long-run interests of shareholders.

These two different views lead to two opposite effects of corporate governance provisions. Thus, it is an empirical issue whether the corporate governance provisions entrench management (a negative effect) or insulate management and allow them to pursue long-term projects (a positive effect). To address this issue, this study uses the audit fee model empirically examines whether audit fees are positively or negatively correlated with Bebchuk et al. (2005) entrenchment index.

\subsection{Audit Fees and Entrenchment Provisions}

As shown by Cohen (2000), external auditors are sensitive to firms' corporate governance and management control in their auditing planning. If entrenchment provisions entrench management and induce non-value maximizing behavior, external auditors will perceive firms with higher level of entrenchment provision as firms with higher risk and thus exercise more audit effort, which leads to higher audit fees. If entrenchment provisions are adopted to attract good managers and induce mangers to pursue long-term projects, external auditors 
will consider firms with higher level of entrenchment provisions as firms with lower risk and thereby exercise less audit effort, which results in lower audit fees. These two competing arguments predict different associations between audit fees and entrenchment provisions. As a result, this study examines the following two competing hypotheses:

Hypothesis 1a: Ceteris paribus, audit fees are positively associated with entrenchment provisions.

Hypothesis 1b: Ceteris paribus, audit fees are negatively associated with entrenchment provisions.

\subsection{Agency Problems}

A stream of empirical research (e.g. Harvey et al. 2004; Gul and Tsui 1998) which suggests that firm's agency problem as an important moderator. In firms with severe agency problems, management entrenchment is more likely to result in opportunistic and inefficient behavior.

Jensen (1986) argues that firms with low growth and high level of free cash flows are more likely to involve in "value destroying activities" and have severe agency problems. The non-value maximizing behavior includes excessive consumption of perquisites, masking of non-optimal expenditures, misappropriation of assets, and salary enhancement (Amihu and Lev 1981; Jensen 1986; Christie and Zimmerman 1994; Rediker and Seth 1995). Both Christie and Zimmerman (1994) and Gul and Tsui (1998) suggest that managers of firms with low growth opportunities and high free cash flows are more likely to mask non-optimal activities by accounting manipulation (Gul \& Tsui 1998, 221) and thus such firms have audit implications in terms of higher inherent audit risks (Gul and Tsui 2001). Consequently, external auditors perceive these firms with high audit risk and exercise more audit effort, which leads to higher audit fees. Thus, we further investigate whether agency problems within firms moderate the association between audit fees and management entrenchment. Two competing hypotheses are composed in this regard:

Hypothesis 2a: Ceteris paribus, agency problems (i.e. low growth and high level of free cash flows) moderate the association between audit fees and entrenchment provisions.

Hypothesis 2b: Ceteris paribus, agency problems (i.e. low growth and high level of free cash flows) do not moderate the association between audit fees and entrenchment provisions.

\section{Methodology}

The OLS audit fee regression model is widely used in prior studies (e.g. Simunic 1980, Francis and Simon 1987, Chan et al. 1983, Gul and Tsui (2001), Ferguson et al. (2003), Francis et al. (2005)). The model uses a set of variables to control for general cross-sectional differences in factors that affect audit fees. Prior studies show that the model has good explanatory power (adjusted $\mathrm{R}^{2}$ is 0.70 or higher) and are robust across different samples, time periods, countries and sensitivity analyses for model misspecification.

Based on prior studies (e.g. Ferguson et al. (2003), Francis et al. (2005), Gul and Tsui (2001)), the following audit fee model is used to examine the association between audit fees and 
management entrenchment:

$L A F=\alpha_{0}+\beta_{1} S I Z E+\beta_{2} L S E G+\beta_{3} C U R R E N T+\beta_{4} Q U I C K+\beta_{5} D E+\beta_{6} R O I+\beta_{7} F O R E I G N$

$+\beta_{8}$ Qopinion $+\beta_{9} Y E+\beta_{10} L O S S+\beta_{11}$ adjFCF $+\beta_{12} E_{-}$index + Fixed effects $+\varepsilon$

$\mathrm{LAF} \quad=\quad$ natural log of total audit fees;

SIZE $=$ natural log of total assets in millions of dollars;

LSEG = natural log of the number of unique business segments;

CURRENT $=$ ratio of current assets to total assets;

QUICK = ratio of current assets less inventory to current liability;

$\mathrm{DE} \quad=\quad$ ratio of long-term debt divided by total assets;

ROI $=$ ratio of earnings before interest and tax to total assets;

FOREIGN $=\quad$ proportion of total sales from foreign operations;

Qopinion = indicator variable, $1=$ qualified audit report;

YE $=$ indicator variable, $1=31 / 12$ fiscal year end;

LOSS $=$ indicator variable, $1=$ loss in current fiscal year;

$\operatorname{adjFCF}=$ Jensen free cash flow; defined as cash flow (revenues less cash expenses including tax and interest payments) less dividends, divided by total assets (Gul \& Tsui 2001; Chirinko \& Schaller 2004);

E_index $\quad=$ Entrechment index (Bebchuk et al. 2005);

Fixed effects $=$ industry dummy variables for two-digit SIC industry classification and year dummy variables;

$\varepsilon \quad=\quad$ error term.

The above model is similar to Francis et al. (2005) except for two variables: adjFCF and E_index. AdjFCF (Jensen free cash flow) is measured in the same way as Gul and Tsui (1998), Gul and Tsui (2001) and Chirinkoand Schaller (2004). E_index is the variable of interest and is the entrenchment index defined by Bebchuk et al. (2005) entrenchment index.

The positive coefficient on E_index suggests that entrenchment provisions entrench management and induce inefficient or opportunistic behavior. The negative coefficient on E_index suggests that entrenchment provisions are adopted to attract good managers to pursue long-term projects. Furthermore, this study investigates whether the relation between audit fees and entrenchment provisions is contingent on firms' agency problem. We expect that the association between audit fees and entrenchment provisions is stronger for firms with agency problems (i.e. firms with low growth and high level of free cash flows).

Following Chirinko \& Schaller (2004) and Gul \& Tsui (2001), free cash flows are defined as cash flow less dividends, divided by total assets; cash flow is defined as revenues less cash 
expenses including tax and interest payments. Following prior research (Chirinko \& Schaller 2004; Harvey et al. 2004; Lang et al. 1991), Tobin's Q, which measures growth opportunities, is computed as market value of equity plus book value of assets minus book value of equity, and then divided by book value of assets. Base on Jensen (1986), this study defines firms with agency problems as the firms with low growth and high level of free cash flows. Firms with Tobin's Q below the full sample median of Tobin's Q are classified as firms with low growth opportunities; while firms with free cash flows above the full sample median free cash flows are classified as high level of free cash flows.

\section{Sample}

The initial sample consists of all firms with data available on Compustat between 2000 and 2004. The sample also meets the following screens: 1) audited by Big N accounting firms; 2) required financial statement data available on Compustat; 3) not in the financial services sector (SIC codes 6000 to 6999); 4) audit fees data available from Standard \& Poor audit fee database; 5) entrenchment provision index available (entrenchment index data are provided by Professor Bebchuk, please refer to his website). Because Bebchuk et al. (2005) get corporate provisions data from IRRC (Investor Responsibility Research Center) and IRRC publications are available only for year 2000, 2002 and 2004, that firms' governance provisions are assumed to be in place during the period immediately following the publication of the volume until the publication of the subsequent IRRC volume, which follows Bebchuck et al. (2005) and Gompers et al. (2003). The final sample meeting the above requirements has 2,510 firm-year observations from 2000 to 2004.

Table 1. Descriptive Statistics

\begin{tabular}{|c|c|c|c|c|c|c|c|}
\hline Variable & Mean & Median & Std Dev & Q1 & Q3 & Minimum & Maximum \\
\hline AUDITFEE & 2071.240 & 931.450 & 3702.940 & 474.000 & 2132.200 & 2.684 & 80593.000 \\
\hline laf & 6.947 & 6.837 & 1.115 & 6.161 & 7.665 & 0.987 & 11.297 \\
\hline assets & 5613.550 & 1368.280 & 13002.970 & 562.101 & 4335.000 & 30.531 & 174278.000 \\
\hline SIZE & 7.418 & 7.221 & 1.512 & 6.332 & 8.374 & 3.419 & 12.068 \\
\hline LSEG & 0.895 & 1.099 & 0.686 & 0.000 & 1.386 & 0.000 & 2.303 \\
\hline CURRENT & 0.461 & 0.443 & 0.201 & 0.317 & 0.606 & 0.028 & 0.969 \\
\hline QUICK & 1.917 & 1.311 & 2.346 & 0.891 & 2.042 & 0.044 & 35.795 \\
\hline $\mathrm{DE}$ & 0.213 & 0.203 & 0.182 & 0.064 & 0.309 & 0.000 & 1.555 \\
\hline ROI & 0.070 & 0.079 & 0.132 & 0.032 & 0.127 & -1.599 & 0.858 \\
\hline FOR & 0.333 & 0.325 & 0.219 & 0.154 & 0.481 & 0.000 & 1.286 \\
\hline Qopinion & 0.476 & 0.000 & 0.500 & 0.000 & 1.000 & 0.000 & 1.000 \\
\hline YE & 0.653 & 1.000 & 0.476 & 0.000 & 1.000 & 0.000 & 1.000 \\
\hline loss & 0.083 & 0.000 & 0.276 & 0.000 & 0.000 & 0.000 & 1.000 \\
\hline $\operatorname{adjFCF}$ & 0.069 & 0.078 & 0.107 & 0.043 & 0.113 & -1.039 & 0.453 \\
\hline E_Index & 2.479 & 3.000 & 1.253 & 2.000 & 3.000 & 0.000 & 6.000 \\
\hline
\end{tabular}

Variables are defined as the following:

AUDITFEE $=$ total audit fees in thousand dollars 


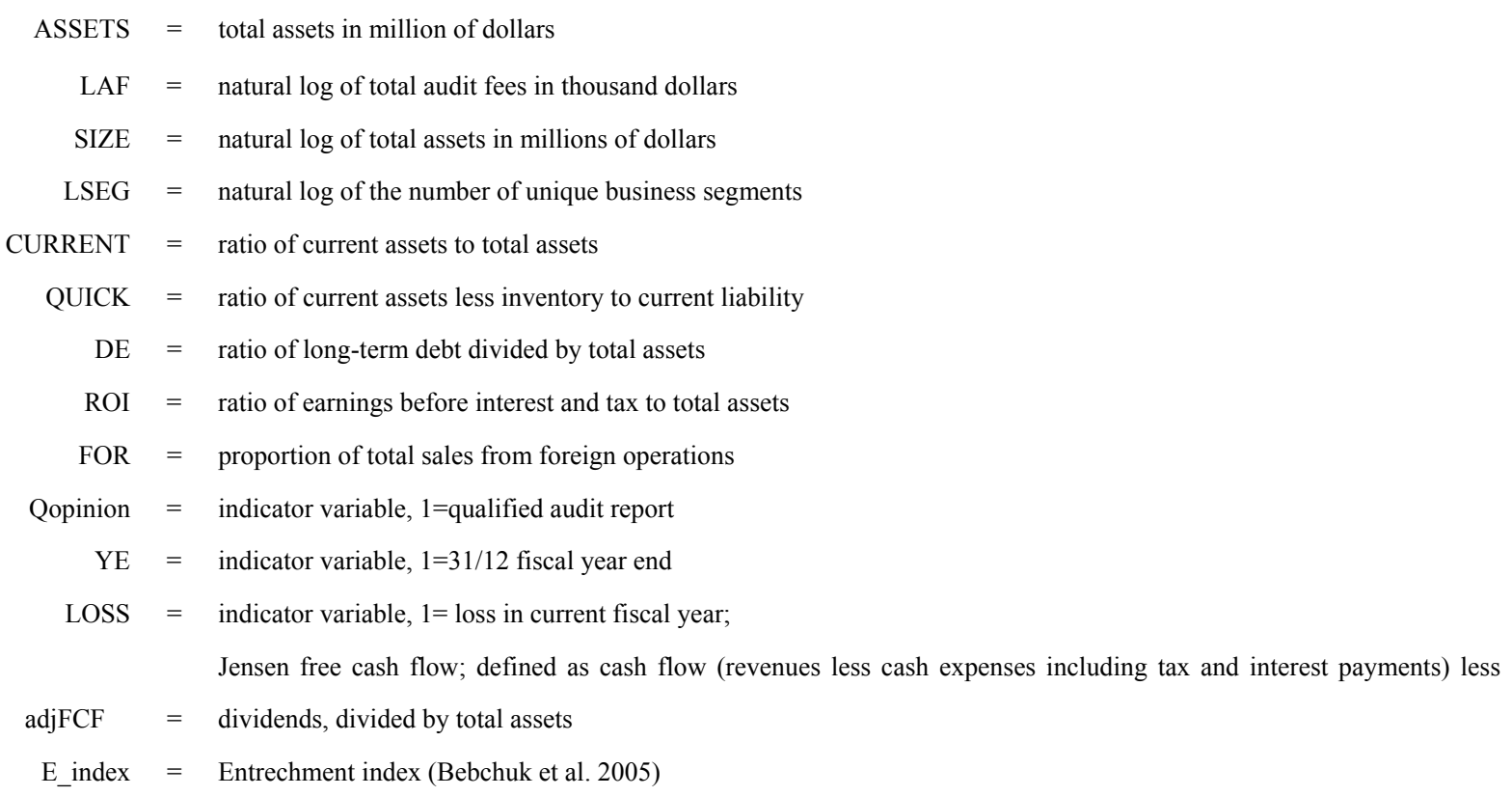

Table 1 provides descriptive statistics. As shown in Table 1, there is a big difference between the mean and median of audit fee and distribution of audit fees is skewed. In contrast, the difference is much smaller for natural $\log$ of audit fees and the distribution of natural $\log$ of audit fees is approximately normal. This provides support for natural log-transformation of audit fee and total assets. 


\section{Empirical Results}

Table 2. Regressions of Audit Fees on Control Variables and Entrenchment Index

\begin{tabular}{lccc}
\hline Variable & \multicolumn{2}{c}{$\begin{array}{c}\text { White } \\
\text { Estimate }\end{array}$} & $\begin{array}{c}\text { p value } \\
\text { Intercept }\end{array}$ \\
SIZE & 2.186 & 16.373 & 0 \\
LSEG & 0.586 & 48.661 & 0 \\
CURRENT & 0.163 & 8.703 & 0 \\
QUICK & 0.581 & 6.6 & 0 \\
DE & -0.061 & -6.324 & 0 \\
ROI & 0.166 & 2.094 & 0.036 \\
FOR & -0.372 & -1.66 & 0.097 \\
Qopinion & 0.653 & 9.576 & 0 \\
YE & 0.121 & 4.054 & 0 \\
loss & 0.157 & 5.336 & 0 \\
adjFCF & 0.069 & 1.187 & 0.235 \\
E_Index & 0.055 & 0.2 & 0.841 \\
y2000 & 0.021 & 2.556 & 0.011 \\
y2001 & -0.773 & -12.914 & 0 \\
y2002 & -0.69 & -11.56 & 0 \\
y2003 & -0.382 & -6.403 & 0 \\
\hline $\mathrm{N}$ & -0.259 & -4.279 & 0 \\
\hline $\mathrm{R}^{2}$ & & 2510 & \\
\hline
\end{tabular}

Variables in the regression are defined as the following:

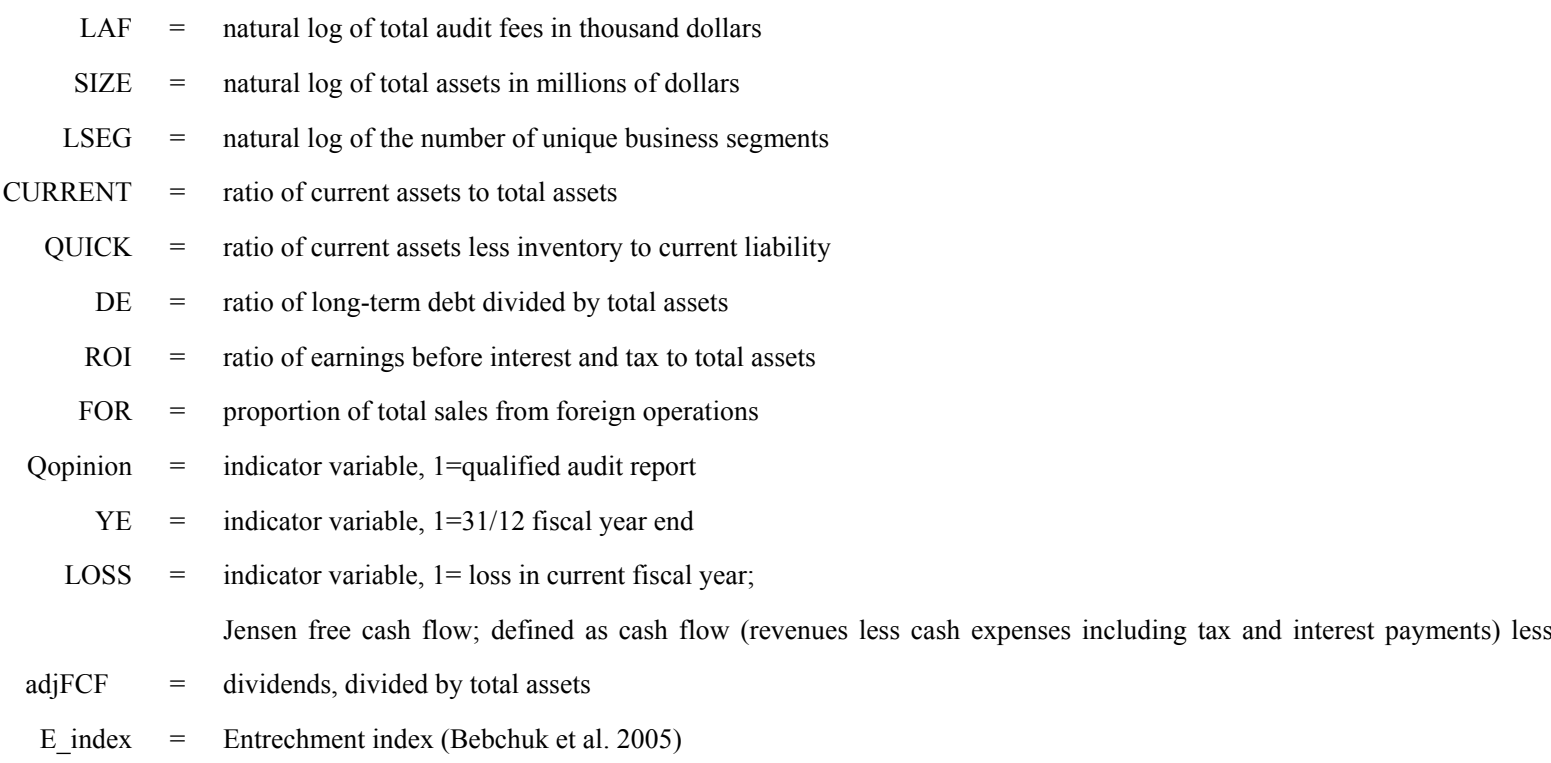

We control the following 34 two-digit SIC industries with more than ten firm year observations: 10, 13, 16, $20,23,24,25,26,27,28,29,30,32,33,34,35,36,37,38,39,42,45,48,49,50,51,54,56,57,58,59,72$, 
73 and 87.

For brevity, we do not report coefficients on two-digit SIC industry dummy variables.

White $\mathrm{t}$ value and white $\mathrm{p}$ value are $\mathrm{t}$ value and $\mathrm{p}$ value based on white (1980) corrected for heteroscedasticity.

Table 2 shows that the coefficient on E_index is 0.021 significant at 0.01 level (white-corrected $\mathrm{p}$ value), supporting hypothesis 1a. Based on the coefficient, an increase of corporate governance provision by one causes the increase of audit fees by around 1,020 dollars. This suggests that entrenchment provisions entrench management and result in high risk perceived by external auditors.

Additionally, the results on other control variables are similar with Francis et al. (2005 Table 4): positive and significant coefficient on SIZE, LSEG, CURRENT, DE, FOR and Qopinion; negative and significant coefficient on QUICK and ROI. The coefficient on YE is positive in this study, but negative in Francis et al. (2005) because Francis et al. (2005) define YE indicator equals one if non December 31 year end and this study defines YE indicator equals one if December 31 year end. Inconsistent with Francis et al. (2005 Table 4), we do not find significant results on indicator variable Loss.

After excluding firms with missing data to compute Tobin's Q, the sample size drops from 2,510 to 2,444 . Among the 2,444 firm year observations, 394 observations are classified as observations with low growth and high level of free cash flows. 
Table 3. Effects of Entrenchment Index on Audit Fees in Two Different Subsamples Panel A: Low growth and high free cash flow Panel B: the other sample

\begin{tabular}{|c|c|c|c|c|c|c|}
\hline Variable & Estimate & $\begin{array}{l}\text { White } \\
\text { t value }\end{array}$ & $\begin{array}{l}\text { White } \\
\mathrm{p} \text { value }\end{array}$ & Estimate & $\begin{array}{l}\text { White } \\
\text { t value }\end{array}$ & $\begin{array}{l}\text { White } \\
\mathrm{p} \text { value }\end{array}$ \\
\hline Intercept & 2.458 & 7.07 & 0 & 2.191 & 14.831 & 0 \\
\hline SIZE & 0.589 & 22.971 & 0 & 0.585 & 42.943 & 0 \\
\hline LSEG & 0.158 & 3.77 & 0 & 0.168 & 7.666 & 0 \\
\hline CURRENT & 0.701 & 2.947 & 0.003 & 0.612 & 6.242 & 0 \\
\hline QUICK & -0.183 & -4.741 & 0 & -0.065 & -6.976 & 0 \\
\hline $\mathrm{DE}$ & 0.209 & 0.631 & 0.528 & 0.138 & 1.636 & 0.102 \\
\hline ROI & -1.789 & -2.659 & 0.008 & -0.153 & -0.654 & 0.513 \\
\hline FOR & 0.488 & 3.04 & 0.003 & 0.653 & 8.584 & 0 \\
\hline Qopinion & 0.181 & 3.129 & 0.002 & 0.117 & 3.511 & 0 \\
\hline YE & 0.105 & 1.565 & 0.119 & 0.163 & 4.713 & 0 \\
\hline loss & 0.337 & 1.709 & 0.088 & 0.05 & 0.863 & 0.388 \\
\hline $\operatorname{adjFCF}$ & 1.067 & 1.149 & 0.251 & -0.27 & -0.923 & 0.356 \\
\hline E_Index & 0.043 & 1.921 & 0.056 & 0.014 & 1.455 & 0.146 \\
\hline y2000 & -0.699 & -5.133 & 0 & -0.801 & -11.828 & 0 \\
\hline y2001 & -0.557 & -4.359 & 0 & -0.728 & -11.287 & 0 \\
\hline y2002 & -0.291 & -2.283 & 0.023 & -0.414 & -6.423 & 0 \\
\hline y2003 & -0.205 & -1.62 & 0.106 & -0.28 & -4.274 & 0 \\
\hline $\mathrm{N}$ & & 394 & & & 2050 & \\
\hline $\mathrm{R}^{2}$ & & 0.813 & & & 0.7336 & \\
\hline
\end{tabular}

Variables in the regression are defined as the following:

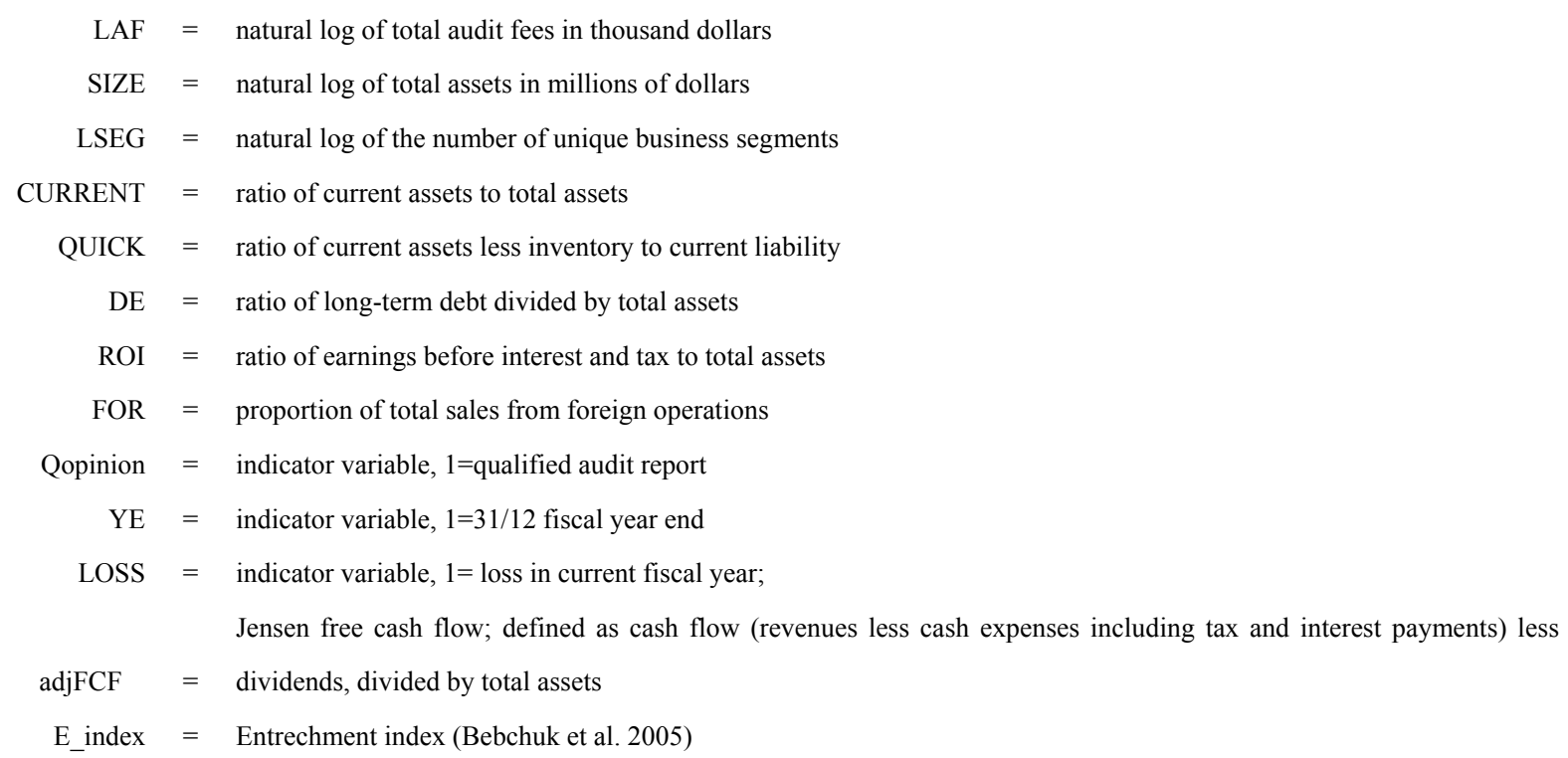

We defined firms with low growth and high free cash flow as firms with below full sample median of Tobin's Q and above full sample median of free cash flow (adjFCF). The rest are in the Others sample.

We control the following 34 two-digit SIC industries with more than ten firm year observations: 10, 13, 16, 
$20,23,24,25,26,27,28,29,30,32,33,34,35,36,37,38,39,42,45,48,49,50,51,54,56,57,58,59,72$, 73 and 87.

For brevity, we do not report coefficient on two-digit SIC industry dummy variables.

White $\mathrm{t}$ value and white $\mathrm{p}$ value are $\mathrm{t}$ value and $\mathrm{p}$ value based on white (1980) corrected for heteroscedasticity.

Table 3 panel A shows that the coefficient on E_index is $0.043(\mathrm{p}=0.044)$ significant at 0.05 level (white-correct $p$ value $=0.056$ ) for the sample with Jensen agency problems (i.e. low growth and high free cash flow). Table 3 panel $\mathrm{B}$ reports that the coefficient on $\mathrm{E}$ index is 0.014 insignificant (white corrected $\mathrm{p}=0.146$ ) for other firms. The coefficient on $\mathrm{E}$ index is three times larger in the agency problem firms (low growth and high free cash flow) than in other firms. Moreover, $\mathrm{R}^{2}$ is higher for the test sample $\left(\mathrm{R}^{2}=0.813\right)$ than for the control sample $\left(\mathrm{R}^{2}=0.734\right)$.

\section{Sensitivity Tests}

We performance several robustness tests and robustness tests show the tenor of the results is unchanged. First, In order to rule out the results are not driven by outliers. We rerun the regression after winsorizing top $1 \%$ and bottom $1 \%$ of outliers. The results are qualitatively the same. Second, we calculate VIF (variance inflation factors) for independent variables and all VIFs are less than ten, which shows that multicollinearity is not a concern. Third, to ease concern on omitted correlated variables, we rerun the regression after controlling for non-audit fees using two stage least square equation models to control for simultaneous determination for audit fees and non-audit fees. The unreported results are qualitatively unchanged. Finally, we also run the regressions with and without controlling for growth (defined by Tobin's Q) and results are similar.

\section{Conclusion}

This study investigates the association between audit fees and management entrenchment (proxied by Bebchuk et al. 2005 entrenchment index). It further investigates whether the association between audit fees and management entrenchment is contingent on firms' agency problems. The results show that audit fees are positively associated with the entrenchment index (Bebchuk et al. 2005). Furthermore, results show that the positive relation between audit fees and the entrenchment index only exists for Jensen agency problem firms (firms with low growth and high free cash flow). These results provide empirical evidence that the association between audit fees and entrenchment provisions is contingent on firms' agency problems.

\section{Acknowledgement}

We acknowledge insightful comments from Professor Suresh Radhakrishnan from University of Texas at Dallas. We also acknowledge research support from the Hong Kong Polytechnic University.

\section{References}

Bebchuk, L., Cohen, A., and Ferrell, A. (2005). What matters in corporate governance? 
Harvard Law School working paper.

Bebchuk, L.A., and Stole, L. (1993). Do short-term managerial objectives lead to under- or over-investment in long-term projects? Journal of Finance 48:719-729. http://dx.doi.org/10.2307/2328920

Bolton, P., and Scharfstein, D. (1990). A theory of predation based on agency problems in financial contracting. American Economic Review 80:93-106.

Brush, T.H., Bromiley, P., and Hendrickx, M. (2000). The free cash flow hypothesis for sales growth and firm performance. Strategic Management Journal 21:455-472. http://dx.doi.org/10.1002/(SICI)1097-0266(200004)21:4<455::AID-SMJ83>3.0.CO;2-P

Chan, P., Ezzamel, M., and Gwilliam, D. (1993). Determinants of audit fees for quoted U.K. companies. Journal of Business Finance and Accounting 20:765-786. http://dx.doi.org/10.1111/j.1468-5957.1993.tb00292.x

Chirinko, R.S., and Schaller, H. (2004). A revealed approach to understanding corporate governance problems: Evidence from Canada. Journal of Financial Economics 74:181-206. http://dx.doi.org/10.1016/j.jfineco.2002.11.001

Christie, A.A., and Zimmerman J. (1994). Efficient and opportunistic choices of accounting procedures: corporate control contests. The Accounting Review 69:539-566.

Coff, R. (2003). Bidding Wars over R\&D intensive firms: knowledge, opportunism, and the market for corporate control. Academy of Management Journal 46:74-85. http://dx.doi.org/10.2307/30040677

Cohen, J.R., and Hanno, D.M. (2000). Auditors' consideration of corporate governance and management control philosophy in preplanning and planning judgments. Auditing: a Journal of Practice and Theory 19:133-146.

Comment, R., and Jarrell, G.A. (1991). The relative signaling power of Dutch-auction and fixed-priced self-tender offers and open market shared repurchases. Journal of Finance 46:1243-1271. http://dx.doi.org/10.2307/2328858

Compers, P., Ishii, J., and Metrick, A. (2003). Corporate governance and equity prices. The Quarterly Journal of Economics 118:107-155. http://dx.doi.org/10.1162/00335530360535162

Francis, J.R., Reichelt, K., and Wang, D. (2005). The pricing of National and city-specific reputations for industry expertise in the U.S. audit market. The Accounting Review 80:113-136. http://dx.doi.org/10.2308/accr.2005.80.1.113

Gul, F., and Tsui, J. (1998). A test of the free cash flow and debt monitoring hypothesis: evidence from audit pricing. Journal of Accounting and Economics 14:219-237.

Gul, F., and Tsui, J. (2001). Free cash flow, debt monitoring, and audit pricing: further evidence on the role of director equity ownership. Auditing: A Journal of Theory and Practice 20:71-84. 
Harvey, C.R., Lins, K.V., and Roper, A. H. (2004). The effect of capital structure when expected agency costs are extreme. Journal of Financial Economics 74:3-30. http://dx.doi.org/10.1016/j.jfineco.2003.07.003

Hart, O, and Moore, J. (1998). Default and renegotiation: a dynamic model of debt. Quarterly Journal of Economics 113:1-41. http://dx.doi.org/10.1162/003355398555496

Jensen, M.C. (1986). Agency costs of free cash flow, corporate finance, and takeovers. American Economic Review 76:323-339.

Jensen, M.C., and Meckling, W.H. (1976). Theory of the firm: managerial behavior, agency costs and ownership structure. Journal of Financial Economics 3:305-360. http://dx.doi.org/10.1016/0304-405X(76)90026-X

Lang, L.H.P., Stulz, R.M., and Walking, R.A. (1991). A test of the free cash flow hypothesis. $\begin{array}{llll}\text { Journal of Financial 29:315-355. } & \text { Economics }\end{array}$ http://dx.doi.org/10.1016/0304-405X(91)90005-5

Le S.A., Walters, B., and Kroll, M. (2006). The moderating effects of external monitors on the relationship between R\&D spending and firm performance. Journal of Business Research 59(2):278-287. http://dx.doi.org/10.1016/j.jbusres.2005.04.003

Lev, B. (2001). Intangible: management, measurement and reporting. Brookings Institution Press.

Lev, B., and Zarowin, P. (1999). The boundaries of financial reporting and how to extend them. Journal of Accounting Research 37:353-385. http://dx.doi.org/10.2307/2491413

Manne, H. (1965). Mergers and the market for corporate control. Journal of Political Economy 73:110-120. http://dx.doi.org/10.1086/259000

Shleifer, A., and Vishny, R. (1997). A survey of corporate governance. Journal of Finance 52:737-783. http://dx.doi.org/10.2307/2329497

Simmunic, D. (1980). The pricing of audit services: Theory and evidence. Journal of Accounting Research 18:161-190. http://dx.doi.org/10.2307/2490397

Stein, J. (1988). Takeover threats and managerial myopia. Journal of Political Economy 96:61-80. http://dx.doi.org/10.1086/261524

White, H. (1980). A heteroskedasticity-consistent covariance matrix estimator and a direct test for heteroskedasticity. Econometrica 48:817-838. http://dx.doi.org/10.2307/1912934

\section{Copyright Disclaimer}

Copyright reserved by the author(s).

This article is an open-access article distributed under the terms and conditions of the Creative Commons Attribution license (http://creativecommons.org/licenses/by/3.0/). 